\title{
The biomimetic synthesis of balsaminone $A$ and ellagic acid via oxidative dimerization
}

\author{
Sharna-kay Daley and Nadale Downer-Riley
}

\author{
Full Research Paper \\ Address: \\ Department of Chemistry, The University of the West Indies, Mona, \\ Jamaica \\ Email: \\ Nadale Downer-Riley* - nadale.downer02@uwimona.edu.jm \\ ${ }^{*}$ Corresponding author \\ Keywords: \\ balsaminone A; biomimetic synthesis; ellagic acid; oxidative \\ dimerization
}

Beilstein J. Org. Chem. 2020, 16, 2026-2031.

doi:10.3762/bjoc.16.169

Received: 27 April 2020

Accepted: 06 August 2020

Published: 18 August 2020

Associate Editor: J. Aubé

(C) 2020 Daley and Downer-Riley; licensee Beilstein-Institut.

License and terms: see end of document.

\begin{abstract}
The application of oxidative dimerization for the biomimetic synthesis of balsaminone A and ellagic acid is described. Balsaminone $\mathrm{A}$ is synthesized via the oxidative dimerization of 1,2,4-trimethoxynaphthalene under anhydrous conditions using CAN, PIDA in $\mathrm{BF}_{3} \cdot \mathrm{OEt}_{2}$ or PIFA in $\mathrm{BF}_{3} \cdot \mathrm{OEt}_{2}$ in $7-8 \%$ yields over 3 steps. Ellagic acid is synthesized from its biosynthetic precursor gallic acid, in $83 \%$ yield over 2 steps.
\end{abstract}

\section{Introduction}

Over the last century, the formation of an aryl to aryl bond has garnered considerable synthetic attention due to the applications of biaryls as pharmaceutical agents, as well as chiral auxiliaries in asymmetric synthesis [1-3]. Methods such as the Ullman coupling, Suzuki-Miyaura coupling and Stille coupling have dominated the field for the synthesis of biaryls $[1,4]$. Throughout the years, the exploration of oxidative dimerization reactions of electron-rich aromatic compounds, such as thiophenes, anilines and alkoxyarenes, in an attempt to establish high-yielding and selective oxidative coupling reactions, has afforded new and greener synthetic protocols for biaryls [5-7]. Several oxidants, such as the salts of $\mathrm{Ag}$ (I\&II) [8], Ti(III\&IV) [9], $\mathrm{Mn}(\mathrm{III})$ [10], $\mathrm{Ce}(\mathrm{IV})$ [11], $\mathrm{Sn}(\mathrm{IV})$ [12] and $\mathrm{Fe}(\mathrm{III})$ [13], as well as the hypervalent iodine reagents phenyliodine diacetate
(PIDA) and phenyliodine bis(trifluoroacetate) (PIFA), have been utilized for oxidative dimerization reactions $[14,15]$. The use of these one-electron oxidants, as well as non-metallic reagents, plays an important role in accessing symmetrical and asymmetrical biaryls and polyaryls [1]. There are many important applications of oxidative dimerization reactions, one of which is the direct synthesis of natural product scaffolds [1,7,16-18]. Examples of this application include the biomimetic synthesis of the bioactive natural products bismurrayaquinone A (1) [16], parvistemin A (2) [17] and violetquinone (3) [18] (Figure 1).

Similar to those natural products, the biomimetic synthesis of balsaminone A (4) and ellagic acid (5) can be attained using ox- 
<smiles>CC1=C(C2=C(C)C(=O)c3c([nH]c4ccccc34)C2=O)C(=O)c2[nH]c3ccccc3c2C1=O</smiles>

bismurrayaquinone $\mathrm{A}(1)$<smiles>CC1=C(O)C(=O)C(CCc2ccccc2)=C(C2=C(CCc3ccccc3)C(=O)C(O)=C(C)C2=O)C1=O</smiles>

parvistemin A (2)<smiles>COc1cc2c3c(oc2c2cc(C)cc(O)c12)C(=O)c1c(O)cc(C)cc1C3=O</smiles>

violet-quinone (3)

Figure 1: Selected natural products synthesized via oxidative dimerization.

idative dimerization reactions, based on their proposed biosynthesis (Scheme 1 and Scheme 2) [19,20]. These pathways, which start with shikimic acid, feature the dimerization of monomeric phenolic precursors by a laccase enzyme, a singleelectron enzyme complex within macro-organisms which facilitates oxidative dimerization through phenolic coupling [19]. In the case of balsaminone A (4), lawsone (6) is methylated to ether 7 which undergoes reduction to the dihydroxynaphthalene 8. This is then dimerized by the copper-rich enzyme to quinone arenol 9, which, following intramolecular cyclization, affords balsaminone A (4, Scheme 1). Similarly, the biosynthetic precursor of ellagic acid (5), gallic acid (10), undergoes dimerization to the dimeric polyphenolic acid $\mathbf{1 1}$, followed by intramolecular cyclization to yield ellagic acid (5, Scheme 2) [20].

Because of the bioactivity of both natural products, there have been previous investigations of the synthesis of balsaminone $\mathrm{A}$ (4) [21,22] and ellagic acid (5) [23]. In our previous synthesis<smiles>CC(C)(C)[C]1CC(C(=O)O)=C[C@H](O)[C@@H]1O</smiles>

shikimic acid<smiles>C[C@H]1C[C@@H]1CC1CC1</smiles>

lawsone (6)<smiles>COC1=CC(=O)c2ccccc2C1=O</smiles>

7 reductase $\checkmark$<smiles>COc1c(O)c2ccccc2c2oc3c(c12)C(=O)c1ccccc1C3=O</smiles>

balsaminone $A(4)$<smiles>[Y]c1c(OC)c(O)c2ccccc2c1O</smiles>

9<smiles>COc1cc(O)c2ccccc2c1O</smiles>

8

Scheme 1: Proposed biosynthesis of balsaminone A (4) [19].

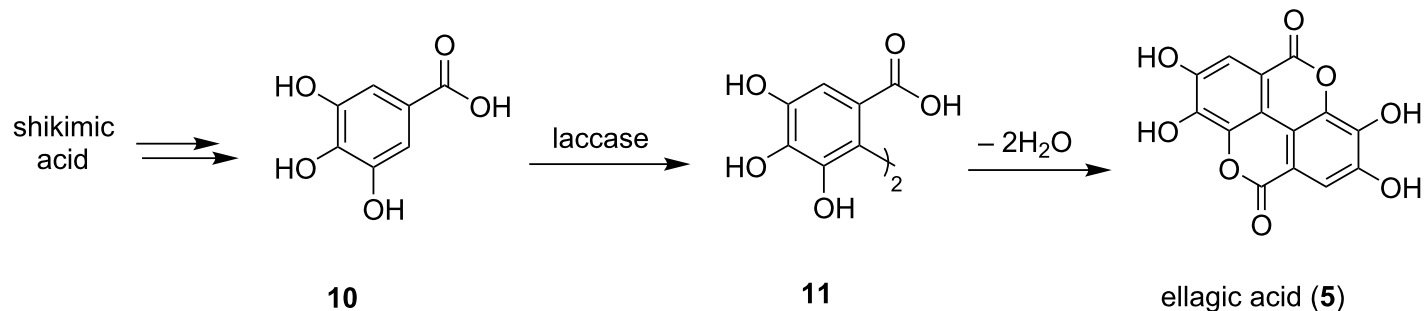


of balsaminone A (4) [22] (Scheme 3), silver oxide was used as the oxidative dimerizing agent for the formation of the binaphthoquinone intermediate 13. This was followed by photolytic cyclisation and ortho-formylation to give carbaldehyde $\mathbf{1 4}$ Conversion to balsaminone A (4) could then be achieved in $57 \%$ yield over 5 steps. The synthesis of ellagic acid (5) on the other hand featured an $o$-chloranil-mediated dimerization of methyl gallate (15), which yielded the natural product in $48 \%$ yield over 5 steps, as reported by Tsuboi et al. (Scheme 3) [23].

\section{Results and Discussion}

\section{Biomimetic synthesis of balsaminone $A$}

With the initial focus being the biomimetic synthesis of balsaminone A (4), well-established methods for the dimerization of phenolic compounds were explored $[8,9]$. As such, a methanolic solution of 2-methoxy-1,4-dihydroxynaphthalene (8), obtained from the reduction of lawsone (6), was subjected to the oxidants activated carbon (Act-C), potassium ferricyanide $\left(\mathrm{K}_{3}\left[\mathrm{Fe}(\mathrm{CN})_{6}\right]\right)$, $p$-benzoquinone and stannic chloride $\left(\mathrm{SnCl}_{4}\right)$. As shown in Scheme 4, with the exception of $\mathrm{SnCl}_{4}$, all oxidants resulted in the re-oxidation of the hydroxylated substrate to naphthoquinone 7. $\mathrm{SnCl}_{4}$, however, while not successful for the synthesis of the desired biomimetic precursor $\mathbf{9}$, afforded the binaphthylquinone 16 in $22 \%$ yield.

Given the initial unsuccessful attempt at the synthesis of the biomimetic precursor of balsaminone A (4), it was evident that alternative oxidative dimerization conditions needed to be explored. The oxidants cerium(IV) ammonium nitrate (CAN), ferric chloride hexahydrate $\left(\mathrm{FeCl}_{3} \cdot 6 \mathrm{H}_{2} \mathrm{O}\right)$, vanadium pentoxide<smiles>COc1ccc(O)c2ccccc12</smiles>

1. o-chloranil, $\mathrm{Et}_{2} \mathrm{O},-40^{\circ} \mathrm{C}$

2. $-40^{\circ} \mathrm{C}$ to rt, $3 \mathrm{~h}$

3. $\mathrm{NaS}_{2} \mathrm{O}_{4}, \mathrm{rt}, 30 \mathrm{~min}$

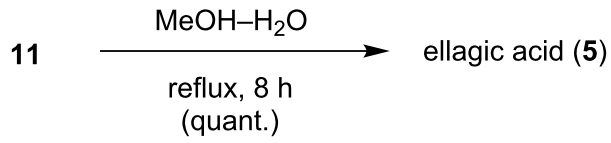

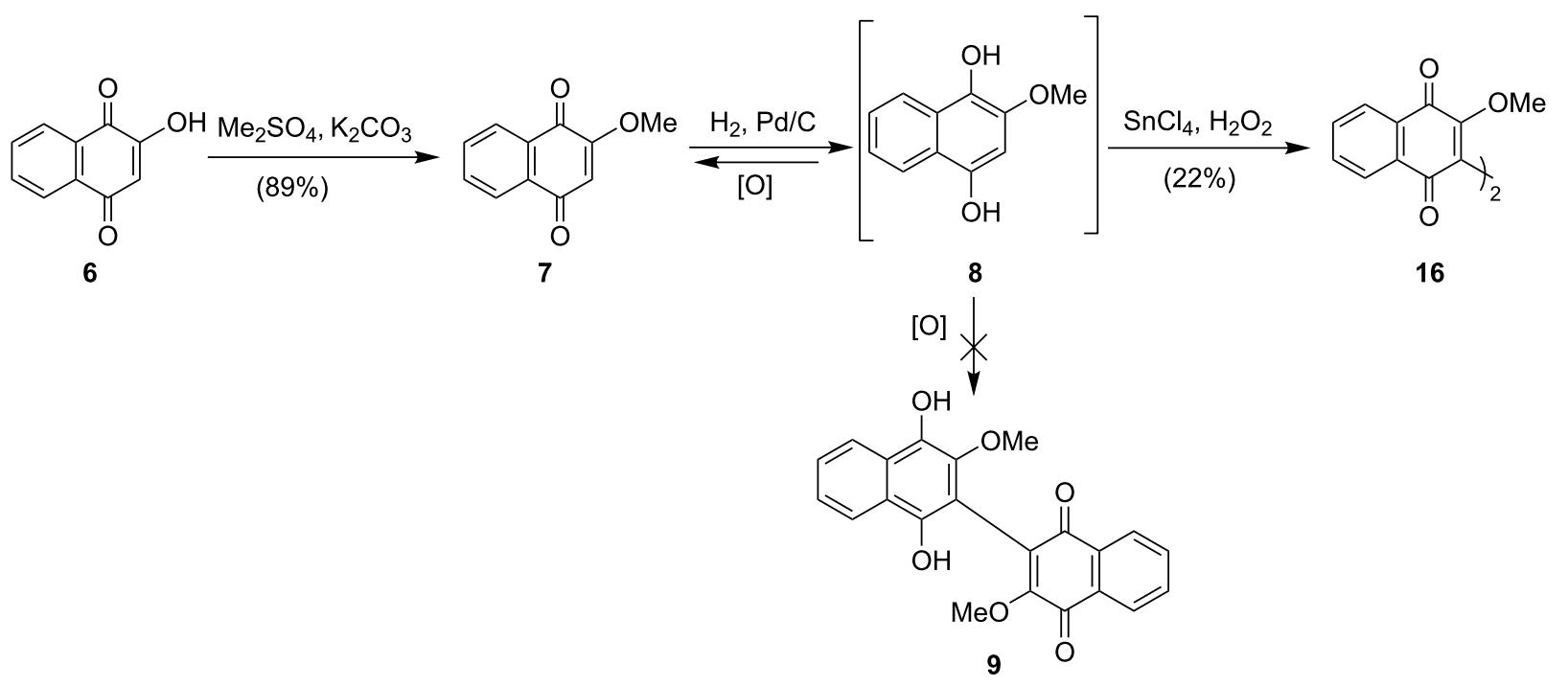


$\left(\mathrm{V}_{2} \mathrm{O}_{5}\right)$, PIFA, and PIDA, in addition to $\mathrm{SnCl}_{4}$, were considered. Also investigated were 2-iodoxybenzoic acid (IBX) because of its implication in single-electron oxidation [24], and chromium trioxide $\left(\mathrm{CrO}_{3}\right)$, which, based on its $\mathrm{Cr}(\mathrm{VI})$ oxidation state, should be able to facilitate single-electron transfer in the presence of electron-rich arenes.

The dimerization of 1,2,4-trimethoxynaphthalene (17) in the presence of the metal oxidants $\mathrm{CAN}, \mathrm{V}_{2} \mathrm{O}_{5}$, and $\mathrm{CrO}_{3}$, afforded binaphthyl 16 in 29, 34, and 19\% yields, respectively (Table 1). As anticipated, the reaction of naphthalene $\mathbf{1 7}$ with CAN under aqueous conditions resulted in preferential oxidative demethylation to give quinone $\mathbf{7}$, as opposed to oxidative dimerization. The elimination of water from the reaction posed a few challenges since the solubility of CAN in organic solvents determines the likelihood of nitration or oxidative dimerization [1]. It was found that dry acetonitrile was more conducive to nitration, whereas methanol afforded the desired biaryl in 55\% yield. In contrast to $\mathrm{CAN}$, both $\mathrm{V}_{2} \mathrm{O}_{5}$ and $\mathrm{CrO}_{3}$ required aqueous conditions to prevent complexation of the reagent and the starting material. Of the Lewis acids used, stannic chloride proved to be the most effective oxidant for dimerization (Table 1). However, the hypervalent iodine reagents PIFA and PIDA gave better results overall, affording dimer $\mathbf{1 8}$ in $63 \%$ and $59 \%$ yields, respectively (Table 1).

Following the successful oxidative dimerization of 1,2,4trimethoxynaphthalene $\mathbf{1 7}$ to biaryl $\mathbf{1 8}$, the biaryl was con- verted quantitatively to binaphthyl $\mathbf{1 6}$ in the presence of an aqueous solution of $\mathrm{CAN}$ at $0{ }^{\circ} \mathrm{C}$. Alternatively, the binaphthylquinone $\mathbf{1 6}$ was synthesized through the oxidation of lawsone (6), in the presence of sodium persulfate, followed by methylation [25]. The cyclization of binaphthyl 16 was then attempted taking into consideration the photolytic cyclization of binaphthyls to form pentacyclic furan derivatives $[8,18,22]$. However, the photolytic cyclization of binaphthyl 16 using a $100 \mathrm{~W}$ bulb was attempted without success, due to degradation of the starting material. This led to a different approach employing a reductive, base-mediated cyclization using alkaline aqueous sodium dithionite. Interestingly, the typical conditions for reduction using dithionite proved too harsh for the substrate, and like the photolysis of the binaphthyl 16, degradation occurred. However, the use of triethylamine instead of aqueous sodium hydroxide resulted in the isolation of balsaminone A (4) in $13 \%$ yield, an overall $7-8 \%$ yield over 3 steps, completing the biomimetic synthesis of the natural product as shown in Scheme 5 .

\section{Synthesis of ellagic acid}

With the synthesis of balsaminone A (4) accomplished, the direct biomimetic synthesis of ellagic acid (5) was targeted. While the synthesis of ellagic acid (5) has been achieved in $48 \%$ yield over four steps by Alam et al. [23], starting from methyl gallate (15), it was anticipated that a more concise and efficient synthesis could be attained. Methyl gallate (15), which may be obtained commercially or from the

Table 1: Reagents and products in the oxidative dimerization of 1,2,4-trimethoxynaphthalene (17).<smiles>COc1cc(OC)c2ccccc2c1OC</smiles>

17

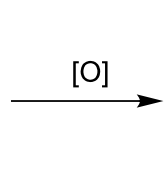<smiles>COC1=C(C)C(=O)c2ccccc2C1=O</smiles>

16<smiles>COc1c(C)c(OC)c2ccccc2c1C</smiles>

18<smiles>COC1=CC(=O)c2ccccc2C1=O</smiles>

7

\begin{tabular}{|c|c|c|c|}
\hline & $16(\%)$ & $18(\%)$ & 7 (\%) \\
\hline $\mathrm{CAN}^{\mathrm{a}}$ & $29^{b}$ & $55^{c}$ & $67^{b}$ \\
\hline $\mathrm{V}_{2} \mathrm{O}_{5}^{\mathrm{a}, \mathrm{b}}$ & 34 & - & - \\
\hline $\mathrm{CrO}_{3}^{\mathrm{a}, \mathrm{b}}$ & 19 & - & 62 \\
\hline $\mathrm{FeCl}_{3} \cdot \mathrm{SiO}_{2}^{\mathrm{a}, \mathrm{c}}$ & 15 & 43 & - \\
\hline $\mathrm{FeCl}_{3} \cdot 6 \mathrm{H}_{2} \mathrm{O}^{\mathrm{a}, \mathrm{c}}$ & - & 8 & - \\
\hline $\mathrm{SnCl}_{4}{ }^{\mathrm{d}}$ & 22 & $48^{d}$ & - \\
\hline $\mathrm{PIDA}, \mathrm{BF}_{3} \cdot \mathrm{OEt}_{2}{ }^{\mathrm{e}, \mathrm{f}}$ & 21 & 59 & - \\
\hline PIFA, $\mathrm{BF}_{3} \cdot \mathrm{OEt}_{2}{ }^{e, f}$ & 12 & 63 & - \\
\hline $\mathrm{IBX}, \mathrm{BF}_{3} \cdot \mathrm{OEt}_{2}{ }^{\mathrm{e}, \mathrm{f}}$ & 13 & - & 45 \\
\hline
\end{tabular}

a Reaction of naphthalene $17(0.5 \mathrm{mmol})$ with oxidant $(1.65 \mathrm{mmol})$ at rt. ${ }^{\mathrm{b}}$ Addition of oxidant in $\mathrm{H}_{2} \mathrm{O}(1 \mathrm{~mL}$, dropwise $)$ to substrate in $\mathrm{CH}_{3} \mathrm{CN}$ or $\mathrm{CH}_{3} \mathrm{OH}$ (1 mL). ${ }^{\mathrm{C}}$ Addition of oxidant (neat) in thirds, to substrate dissolved in $\mathrm{CH}_{3} \mathrm{CN}$. ${ }^{\mathrm{d}}$ Reaction was carried out in $\mathrm{CH}_{2} \mathrm{Cl}_{2}$ at $100{ }^{\circ} \mathrm{C}$ in a sealed tube.

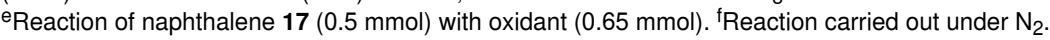


<smiles>COc1cc(OC)c2ccccc2c1OC</smiles>

18<smiles>[Y]C1=C(OC)C(=O)c2ccccc2C1=O</smiles>

1. $\mathrm{Na}_{2} \mathrm{~S}_{2} \mathrm{O}_{8}, \mathrm{NaOH}$

2. $\mathrm{TMSCHN}_{2}$

$(30 \%)$, ref. [25]
16

$\mathrm{Na}_{2} \mathrm{~S}_{2} \mathrm{O}_{4}, \mathrm{Et}_{3} \mathrm{~N}$

$(13 \%)$<smiles>COc1c(O)c2ccccc2c2oc3c(c12)C(=O)c1ccccc1C3=O</smiles>

balsaminone $\mathrm{A}(\mathbf{4})$

Scheme 5: Biomimetic synthesis of balsaminone A (4).

methylation of gallic acid (10) [23], was subjected to the oxidants CAN, PIDA, $\mathrm{FeCl}_{3} \cdot 6 \mathrm{H}_{2} \mathrm{O}$, and $\mathrm{FeCl}_{3} \cdot \mathrm{SiO}_{2}$. Treatment of the polyphenol with PIDA ( 1.5 equiv) in boron trifluoride etherate $(1.5 \mathrm{~mL})$ at room temperature proved to be the most successful dimerization protocol, as the dimeric precursor 19 was formed in $80 \%$ yield after 16 hours. The biaryl 19 was converted quantitatively to the natural product when heated at reflux in aqueous methanol (1:1) for 24 hours. However, allowing the PIFA reaction mixture to stir at room temperature for 24 hours resulted in complete cyclization, affording the natural product 5 in $83 \%$ yield directly from methyl gallate (15, Scheme 6), an improvement for the synthesis of the bioactive natural product.

\section{Conclusion}

The synthesis of balsaminone A (4) is reported in 7-8\% yield over 3 steps from 1,2,4-trimethoxynaphthalene (17). Also, the one-step synthesis of ellagic acid (5) from methyl gallate (15) in $83 \%$ yield is described. These biosynthetically-driven syntheses represent the most efficient routes to these bioactive natural products to date.

\section{Supporting Information}

\section{Supporting Information File 1}

Experimental part.

[https://www.beilstein-journals.org/bjoc/content/ supplementary/1860-5397-16-169-S1.pdf]

\section{Funding}

The authors thank the Department of Chemistry, The University of the West Indies, Mona, Jamaica for support of this work.

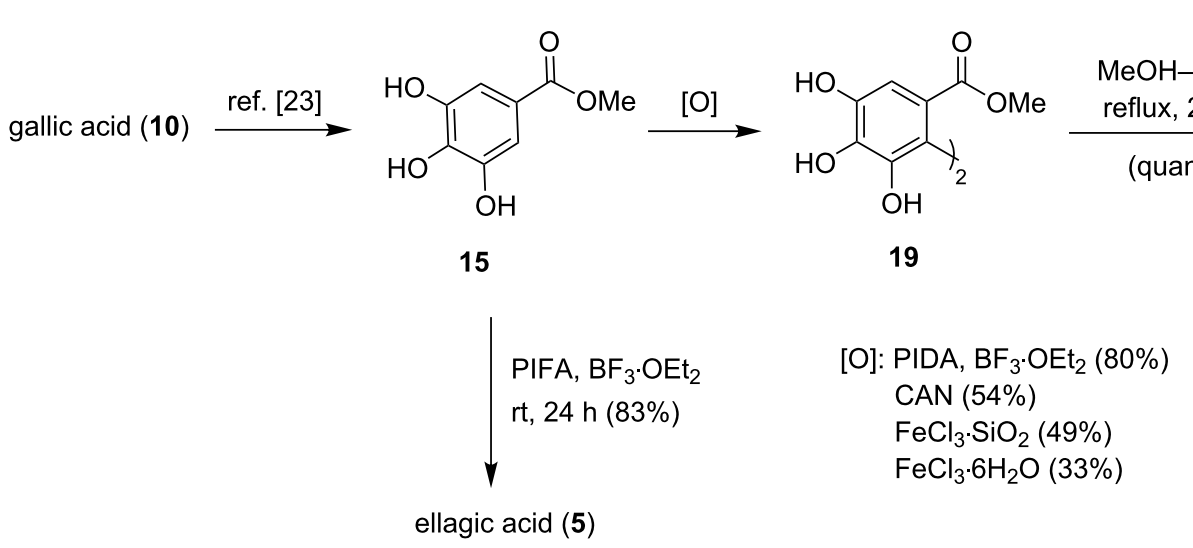




\section{ORCID ${ }^{\circledR}$ iDs}

Nadale Downer-Riley - https://orcid.org/0000-0002-2850-1726

\section{References}

1. Cepanec, I. The Synthesis of Biaryls; Elsevier Science: Oxford, U.K., 2004; pp 2-3.

2. Smrcina, M.; Polakova, J.; Vyskocil, S.; Kocovsky, P. J. Org. Chem. 1993, 58, 4534-4538. doi:10.1021/jo00069a010

3. Chen, Y.; Yekta, S.; Yudin, A. K. Chem. Rev. 2003, 103, 3155-3212. doi:10.1021/cr020025b

4. Sperotto, E.; van Klink, G. P. M.; van Koten, G.; de Vries, J. G. Dalton Trans. 2010, 39, 10338-10351. doi:10.1039/c0dt00674b

5. Sarhan, A. A. O.; Bolm, C. Chem. Soc. Rev. 2009, 38, 2730-2744. doi:10.1039/b906026j

6. Ashenhurst, J. A. Chem. Soc. Rev. 2010, 39, 540-548. doi:10.1039/b907809f

7. Yang, Y.; Lan, J.; You, J. Chem. Rev. 2017, 117, 8787-8863. doi:10.1021/acs.chemrev.6b00567

8. Takeya, T.; Kondo, H.; Otsuka, T.; Tomita, K.; Okamoto, I.; Tamura, O. Org. Lett. 2007, 9, 2807-2810. doi:10.1021/ol070951i

9. Otsuka, T.; Okamoto, I.; Kotani, E.; Takeya, T. Tetrahedron Lett. 2004, 45, 2643-2647. doi:10.1016/j.tetlet.2004.01.133

10. Jasch, H.; Scheumann, J.; Heinrich, M. R. J. Org. Chem. 2012, 77, 10699-10706. doi:10.1021/jo301980j

11. Love, B. E.; Duffy, B. C.; Simmons, A. L. Tetrahedron Lett. 2014, 55 , 1994-1997. doi:10.1016/j.tetlet.2014.02.017

12. Takeya, T.; Doi, H.; Ogata, T.; Okamoto, I.; Kotani, E. Tetrahedron 2004, 60, 9049-9060. doi:10.1016/j.tet.2004.07.073

13. Li, X.-L.; Huang, J.-H.; Yang, L.-M. Org. Lett. 2011, 13, 4950-4953. doi:10.1021/ol202058r

14. Kar, A.; Mangu, N.; Kaiser, H. M.; Beller, M.; Tse, M. K. Chem. Commun. 2008, 386-388. doi:10.1039/b714928j

15. Guo, W.; Faggi, E.; Sebastián, R. M.; Vallribera, A.; Pleixats, R.; Shafir, A. J. Org. Chem. 2013, 78, 8169-8175. doi:10.1021/j0401001k

16. Bringmann, G.; Tasler, S. Tetrahedron 2001, 57, 331-343. doi:10.1016/s0040-4020(00)00940-6

17. Smith, M. J.; Nawrat, C. C.; Moody, C. J. Org. Lett. 2011, 13, 3396-3398. doi:10.1021/ol201246e

18. Ogata, T.; Okamoto, I.; Kotani, E.; Takeya, T. Tetrahedron 2004, 60, 3941-3948. doi:10.1016/j.tet.2004.03.038

19. Manitto, P. Biosynthesis of Natural Products; Ellis Horwood Ltd.: Chichester, U.K., 1981; pp 98-100.

20. Ishikura, N.; Hayashida, S.; Tazaki, K. Bot. Mag., Tokyo 1984, 97, 355-367. doi:10.1007/bf02488668

21. Padwal, J.; Lewis, W.; Moody, C. J. J. Org. Chem. 2011, 76, 8082-8087. doi:10.1021/j0201395n

22. Daley, S.-k. A.; Downer-Riley, N. K. Synlett 2019, 30, 325-328. doi:10.1055/s-0037-1611975

23. Alam, A.; Takaguchi, Y.; Tsuboi, A. J. Fac. Environ. Sci. Technol., Okayama Univ. 2005, 10, 111-117.

24. Wirth, T. Angew. Chem., Int. Ed. 2001, 40, 2812-2814. doi:10.1002/1521-3773(20010803)40:15<2812::aid-anie2812>3.0.co;2$\mathrm{x}$

25. Qi, C.; Wang, W.; Reichl, K. D.; McNeely, J.; Porco, J. A., Jr. Angew. Chem., Int. Ed. 2018, 57, 2101-2104. doi:10.1002/anie.201711535

\section{License and Terms}

This is an Open Access article under the terms of the Creative Commons Attribution License (http://creativecommons.org/licenses/by/4.0). Please note that the reuse, redistribution and reproduction in particular requires that the authors and source are credited.

The license is subject to the Beilstein Journal of Organic Chemistry terms and conditions: (https://www.beilstein-journals.org/bjoc)

The definitive version of this article is the electronic one which can be found at: doi:10.3762/bjoc.16.169 